\title{
Cell Culture Technologies in Successful Biosimilar Development
}

\author{
Jun Yuan, Wayne WenYan Xu, Henry XiaoYu Yu, Lothar Yuling Jiang, \\ H Fai Poon* \\ Quacell Biotechnology Ltd, Zhongshan, Guangdong, China
}

*Corresponding author: H Fai Poon, Quacell Biotechnology Ltd, Zhongshan, Guangdong, China, Tel: +86 15267077477; Email: fai@quacell.com, hungfaipoon@gmail.com

\section{Review Article}

Volume 2 Issue 3

Received Date: June 15, 2018

Published Date: June 29, 2018

\begin{abstract}
The commercial success and expiring patents of biological therapeutics has made biosimilars become attractive to pharmaceutical companies. However, the cost of manufacturing biosimilars has remained a challenge for many companies. Therefore, the ability to mimic the biologically active molecule at the lowest possible cost via cell culture has become the key of successful biosimilar development. Hence, we review current cell culture technologies that are relevant to biosimilar development. The cell line, culture media and bioprocess technology platforms discussed in current review lays a good scientific foundation for the technological competitiveness of biosimilar companies.
\end{abstract}

Keywords: Biosimilar; Robust; Cell; Biopharmaceutical

\section{Introduction}

The commercial success and expiring patents of biological therapeutics has made biosimilars become attractive to pharmaceutical companies [1]. Biosimilars is an attractive mechanism for cost reduction of health care $[2,3]$. The abbreviated biosimilar approval pathway is often required to ensure the long-term safety and efficacy of a biosimilar. However, the cost of manufacturing and licensing a biosimilar product remains high [4]. Reduction of manufacturing cost has become one of the most important technological advantages for a biosimilar developer. Therefore, the ability to mimic the biologically active molecule at the lowest possible cost via cell culture has become the key of successful biosimilar development
[5-9]. The priority of biosimilar companies is to acquire and develop cell culture technology platforms that enable them to manufacture biologics that are similar to reference products; and to produce these products consistently and economically. Hence, we review current cell culture technologies that are relevant to biosimilar development.

\section{Cell Line Engineering}

The increasingly competitive biosimilar marketplace requires biosimilar companies to focus on rapid and low cost cell line development with predictable product quality attributes [10-14]. Traditional stable cell line platform involves selection pressure (such as GS, DHFR 


\section{Bioequivalence \& Bioavailability International Journal}

system) to enhance and isolate clones with high expression of the protein of the gene of interest (GOI). However, the GOI is usually randomly integrated into the host cell's genome, hence it creates heterogeneity and expression instability. Other factors that contribute to instability of the traditional cell line platform include gene copy number, position effect, insertional mutagenesis, post-transcriptional and post-translational modifications $[11,14]$. These clonal instabilities can be solved by a combination of host cell clone selection and vector design to generate a stable cell line that is suitable for production $[14,15]$. Site-specific integration and other new technologies were developed to increase clonal stability while minimizing clonal variation $[14,16]$. However, such technology might reduce the chance to obtain a "high similarity clone" to the reference product. Nevertheless, a predictable technology will also win out in the risk averse pharmaceutical industry.

\section{Media Development}

Media development is one of the keys to biosimilar development. The many components of a typical media provides factors to be adjusted for protein quality optimization [17-19]. Optimization of culture conditions for cell line presents challenges because the diverse nutritional requirements are different clonally. High throughput screening of a library of diverse CHO media formulations with sophisticated Design of Experiment (DOE) experimental design and analysis techniques to develop a new strategic approach to medium development [18]. While formulation of the media is important, a consistent manufacturing process is also necessary to provide a robust production process for biosimilars [20]. However, current cell culture media manufacturing technology still lacks the assurance that the biopharmaceutical companies desire [21]. In recent years, some culture media technologies, such as high throughput technology, multivariate analysis, and study of stability etc., were adapted to improve the media formulation and production of culture media [18,21-25]. It is hopeful that more technologies of cell culture media will be developed and implemented by biopharmaceutical companies for a more robust production process.

\section{Bioprocess Development}

The key of bioprocess development is to develop a process that can consistently produce sufficient amounts of the desired protein with a high level of quality. A typical manufacturing process is divided into upstream and downstream processes. The upstream process involves cell culture technologies of cell expansion and expression [26-29]. Control Strategy the cell culture process are developed based upon scientific and risk management principles because it impact the safety and

quality of the therapeutics being produced [26-28]. Regulatory agencies emphasize analysis and characterization of products in relation to the cell culture processes; setting process specifications; and identifying critical quality attributes (CQA) and critical process parameters [26,30,31]. Moreover, process analytical technology(PAT) guidance was issued to help design, develop, and implement analytical tools during manufacturing and quality assurance of biologics $[32,33]$. The concept of "quality by design" (QbD) was also recommended by regulatory agencies to promote the understanding of the relationship between the product quality and the manufacturing process that enables quality built-in from the beginning of product development to the end of the manufacturing process ${ }^{32}$. The QbD approach in process development usually starts by risk assessment of the process parameter and its impact on CQAs. DOE is then used to screen factors for significant influences on CQAs. The design spaces are then explored in qualified scale down models such as: shake flasks, bench scale bioreactors, pilot scale bioreactors, etc. Building small scale models facilitates the control strategy for the process. When scaling up to production scale, the scaled down models need to be qualified by demonstrating their representation and prediction of large scale production, as well as various scales of operation. The scaled down model can then be used to determine the limits of the design space for the production scale [23,34-38]. The end result of these procedures should be a set of acceptable parameter ranges that conform to the engineering design space for commercial production operations $[39,40]$.

\section{Conclusion Remarks}

The European Union (EU) has been the first to establish a regulatory framework for marketing authorization application (MAA) and has labeled copy cat bio therapeutic products "biosimilars", a term also recently adopted by the US FDA [30,41]. Successful biosimilars development strategies rely on platform technology to rapidly develop the cell culture production system that can consistently produce high quality biosimilars at low cost. The know-how of cell culture in biosimilars development along with technical staff trainingis critical for successful implementation [41-60]. The cell culture technology platforms discussed in current review lays a good scientific foundation for the technological competitiveness of biosimilar companies [61-98]. 


\section{Bioequivalence \& Bioavailability International Journal}

\section{References}

1. Helguera G, Penichet ML (2005) Antibody-cytokine fusion proteins for the therapy of cancer. Methods Mol Med 109: 347-374.

2. Kennedy PJ, Oliveira C, Granja PL, Sarmento B (2018) Monoclonal antibodies: technologies for early discovery and engineering. Crit Rev Biotechnol 38(3): 394-408.

3. Stern M, Herrmann R (2005) Overview of monoclonal antibodies in cancer therapy: present and promise. Crit Rev Oncol Hematol 54(1): 11-29.

4. Bohlega S, Al-Shammri S, Al Sharoqi I, Dahdaleh M, Gebeily S, et al. (2008) Biosimilars: opinion of an expert panel in the Middle East. Curr Med Res Opin 24(10): 2897-2903.

5. Khraishi M, Stead D, Lukas M, Scotte F, Schmid H (2016) Biosimilars: A Multidisciplinary Perspective. Clin Ther 38(5): 1238-1249.

6. Ledford H (2010) 'Biosimilar' drugs poised to penetrate market. Nature 468(7320): 18-19.

7. Tsiftsoglou AS, Ruiz S, Schneider CK (2013) Development and regulation of biosimilars: current status and future challenges. BioDrugs 27(3): 203211.

8. Joung J, Robertson JS, Griffiths E, Knezevic I, Group WHOIC (2008) WHO informal consultation on regulatory evaluation of therapeutic biological medicinal products held at WHO Headquarters, Geneva, 19-20 April 2007. Biologicals 36(4): 269-276.

9. Camacho LH (2017) Current Status of Biosimilars in Oncology. Drugs 77(9): 985-997.

10. Cortes J, Curigliano G, Dieras V (2014) Expert perspectives on biosimilar monoclonal antibodies in breast cancer. Breast Cancer Res Treat 144(2): 233239.

11. Sjogren J, Olsson F, Beck A (2016) Rapid and improved characterization of therapeutic antibodies and antibody related products using IdeS digestion and subunit analysis. Analyst 141(11): 3114-3125.
12. Calvo B, Zuniga L (2012) Therapeutic monoclonal antibodies: strategies and challenges for biosimilars development. Curr Med Chem 19(26): 4445-4450.

13. Brennan FR, Baumann A, Blaich G, de Haan L, Fagg R, et al. (2015) Nonclinical safety testing of biopharmaceuticals--Addressing current challenges of these novel and emerging therapies. Regul Toxicol Pharmacol 73(1): 265-275.

14. Wadhwa M, Thorpe $R$ (2009) The challenges of immunogenicity in developing biosimilar products. IDrugs 12(7): 440-444.

15. Markus R, Liu J, Ramchandani M, Landa D, Born T, et al. (2017) Developing the Totality of Evidence for Biosimilars: Regulatory Considerations and Building Confidence for the Healthcare Community. Bio Drugs 31(3): 175-187.

16. Cai XY, Thomas J, Cullen C, Gouty D (2012) Challenges of developing and validating immunogenicity assays to support comparability studies for biosimilar drug development. Bioanalysis 4(17): 2169-2177.

17. Kuriakose A, Chirmule N, Nair P (2016) Immunogenicity of Biotherapeutics: Causes and Association with Posttranslational Modifications. J Immunol Res 2016: 18.

18. Shriver Z, Trevejo JM, Sasisekharan R (2015) Antibody-Based Strategies to Prevent and Treat Influenza. Front Immunol 6: 315.

19. Salfeld JG (2004) Use of new biotechnology to design rational drugs against newly defined targets. Best Pract Res Clin Rheumatol 18(1): 81-95.

20. Ogura M (2002) Development of monoclonal antibody therapy for malignant lymphoma. Nihon Rinsho 60(3): 505-516.

21. Kamada H (2016) Development of a Drug Discovery Method Targeted to Stromal Tissue. Yakugaku Zasshi 136(3): 435-441.

22. Geng SB, Cheung JK, Narasimhan C, Shameem M, Tessier PM (2014) Improving monoclonal antibody selection and engineering using measurements of colloidal protein interactions. J Pharm Sci 103(11): 3356-3363.

23. Caravella JA, Wang D, Glaser SM, Lugovskoy A (2010) Structure-Guided Design of Antibodies. Curr Comput Aided Drug Des 6(2): 128-138. 


\section{Bioequivalence \& Bioavailability International Journal}

24. Pavlou AK, Belsey MJ (2005) The therapeutic antibodies market to 2008. Eur J Pharm Biopharm 59(3): 389-396.

25. Nieri P, Donadio E, Rossi S, Adinolfi B, Podesta A (2009) Antibodies for therapeutic uses and the evolution of biotechniques. Curr Med Chem 16(6): 753-779.

26. Ebbers HC, van Meer PJ, Moors EH, Mantel-Teeuwisse AK, Leufkens HG, et al. (2013) Measures of biosimilarity in monoclonal antibodies in oncology: the case of bevacizumab. Drug Discov Today 18(1718): 872-879.

27. Sorgel F, Lerch H, Lauber T (2010) Physicochemical and biologic comparability of a biosimilar granulocyte colony-stimulating factor with its reference product. Bio Drugs 24(6): 347-357.

28. Orlova NA, Kovnir SV, Vorobiev, II, Yuriev AS, Gabibov AG, et al. (2012) Stable Expression of Recombinant Factor VIII in CHO Cells Using Methotrexate-Driven Transgene Amplification. Acta Naturae 4(1): 93-100.

29. Le H, Vishwanathan N, Jacob NM, Gadgil M, Hu WS (2015) Cell line development for biomanufacturing processes: recent advances and an outlook. Biotechnol Lett 37(8): 1553-1564.

30. Hurst S, Ryan AM, Ng CK, McNally JM, Lorello LG, et al. (2014) Comparative nonclinical assessments of the proposed biosimilar PF-05280014 and trastuzumab (Herceptin((R))). Bio Drugs 28(5): 451-459.

31. Goncalves J, Araujo F, Cutolo M, Fonseca JE (2016) Biosimilar monoclonal antibodies: preclinical and clinical development aspects. Clin Exp Rheumatol 34(4): 698-705.

32. Elgundi Z, Reslan M, Cruz E, Sifniotis V, Kayser V (2016) The state-of-play and future of antibody therapeutics. Adv Drug Deliv Rev 1(122): 2-19.

33. Hou JJ, Hughes BS, Smede M, Leung KM, Levine K, et al. (2014) High-throughput ClonePix FL analysis of mAb-expressing clones using the UCOE expression system. N Biotechnol 31(3): 214-220.

34. Barnes LM, Bentley CM, Dickson AJ (2003) Stability of protein production from recombinant mammalian cells. Biotechnol Bioeng 81(6): 631-639.

35. Keeler KJ, Dray T, Penney JE, Gloor GB (1996) Gene targeting of a plasmid-borne sequence to a double- strand DNA break in Drosophila melanogaster. Mol Cell Biol 16(2): 522-528.

36. Tsuruta LR, Lopes dos Santos M, Moro AM (2015) Biosimilars advancements: Moving on to the future. Biotechnol Prog 31(5): 1139-1149.

37. Kuhlmann M, Covic A (2006) The protein science of biosimilars. Nephrol Dial Transplant 21(5): v4-8.

38. Goldsmith D, Kuhlmann M, Covic A (2007) Through the looking glass: the protein science of biosimilars. Clin Exp Nephrol 11(3): 191-195.

39. Kirchhoff CF, Wang XM, Conlon HD, Anderson S, Ryan AM, et al. (2017) Biosimilars: Key regulatory considerations and similarity assessment tools. Biotechnol Bioeng 114(2): 2696-2705.

40. Jacobs I, Petersel D, Shane LG, Ng CK, Kirchhoff C, et al. (2016) Monoclonal Antibody and Fusion Protein Biosimilars Across Therapeutic Areas: A Systematic Review of Published Evidence. Bio Drugs. 30(6): 489523.

41. Bui LA, Hurst S, Finch GL, Ingram B, Jacobs IA, et al. (2015) Key considerations in the preclinical development of biosimilars. Drug Discov Today 20(1): 3-15.

42. Al-Sabbagh A, Olech E, McClellan JE, Kirchhoff CF (2016) Development of biosimilars. Semin Arthritis Rheum 45(5): S11-8.

43. Elgundi Z, Sifniotis V, Reslan M, Cruz E, Kayser V (2017) Laboratory Scale Production and Purification of a Therapeutic Antibody. J Vis Exp (119).

44. US Food and Drug Administration: PAT guidance for industry-a framework for innovative pharmaceutical development, manufacturing and quality assurance. http://wwwfdagov/downloads/Drugs/Guidances/uc m070305pdf).

45. Rathore AS, Winkle H (2009) Quality by design for biopharmaceuticals. Nat Biotechnol 27(1): 26-34.

46. Jenzsch M, Bell C, Buziol S, Kepert F, Wegele H, et al. (2017) Trends in Process Analytical Technology: Present State in Bioprocessing. Adv Biochem Eng Biotechnol.

47. Von Stosch M, Hamelink JM, Oliveira R (2016) Toward intensifying design of experiments in 


\section{Bioequivalence \& Bioavailability International Journal}

upstream bioprocess development: An industrial Escherichia coli feasibility study. Biotechnol Prog. 32(5): 1343-1352.

48. Mercier SM, Diepenbroek B, Wijffels RH, Streefland M (2014) Multivariate PAT solutions for biopharmaceutical cultivation: current progress and limitations. Trends Biotechnol 32(6): 329-336.

49. Doherty M, Bones J, McLoughlin N, Telford JE, Harmon B, et al. (2013) An automated robotic platform for rapid profiling oligosaccharide analysis of monoclonal antibodies directly from cell culture. Anal Biochem 442(1): 10-18.

50. Mercier SM, Diepenbroek B, Dalm MC, Wijffels RH, Streefland M (2013) Multivariate data analysis as a PAT tool for early bioprocess development data. J Biotechnol 167(3): 262-270.

51. Le H, Kabbur S, Pollastrini L, Sun Z, Mills K, et al. (2012) Multivariate analysis of cell culture bioprocess data--lactate consumption as process indicator. J Biotechnol 162(2-3): 210-223.

52. Yu LX, Amidon G, Khan MA, Hoag SW, Polli J, et al. (2014) Understanding pharmaceutical quality by design. AAPS J 16(4): 771-783.

53. Yu LX (2008) Pharmaceutical quality by design: product and process development, understanding, and control. Pharm Res 25(4): 781-791.

54. Papantoniou I, Chai YC, Luyten FP, Schrooten Ir J (2013) Process quality engineering for bioreactordriven manufacturing of tissue-engineered constructs for bone regeneration. Tissue Eng Part C Methods 19(8): 596-609.

55. Junker B, Kosinski M, Geer D, Mahajan R, Chartrain M, et al. (2011) Design-for-Six-Sigma for Development of a Bioprocess Quality-by-Design Framework. PDA J Pharm Sci Technol 65(3): 254-286.

56. Van Aerts LA, De Smet K, Reichmann G, van der Laan JW, Schneider CK (2014) Biosimilars entering the clinic without animal studies. A paradigm shift in the European Union. MAbs 6(5): 1155-1162.

57. Smolen JS, Cohen SB, Tony HP, Scheinberg M, Kivitz A, et al. (2017) A randomised, double-blind trial to demonstrate bioequivalence of GP2013 and reference rituximab combined with methotrexate in patients with active rheumatoid arthritis. Ann Rheum Dis 76(9): 1598-1602.

58. Alten $R$ (2015) Biosimilars in rheumatology. Development and results of clinical trials. Z Rheumatol 74(8): 682-688.

59. Azevedo VF, Galli N, Kleinfelder A, D'Ippolito J, Urbano PC (2015) Etanercept biosimilars. Rheumatol Int 35(2): 197-209.

60. Colletti KS (2013) Conference Report: Bioanalysisrelated topics presented at the International Conference and Exhibition on Biowaivers and Biosimilars. Bioanalysis 5(5): 529-531.

61. Derzi M, Johnson TR, Shoieb AM, Conlon HD, Sharpe $\mathrm{P}$, et al. (2016) Nonclinical Evaluation of PF06438179: A Potential Biosimilar to Remicade(R) (Infliximab). Adv Ther 33(11): 1964-1982.

62. Declerck P, Farouk-Rezk M, Rudd PM (2016) Biosimilarity Versus Manufacturing Change: Two Distinct Concepts. Pharm Res 33(2): 261-268.

63. Blauvelt A, Cohen AD, Puig L, Vender R, Van der Walt J, et al. (2016) Biosimilars for psoriasis: preclinical analytical assessment to determine similarity. $\mathrm{Br} \mathrm{J}$ Dermatol 174(2): 282-286.

64. Berkowitz SA, Engen JR, Mazzeo JR, Jones GB (2012) Analytical tools for characterizing biopharmaceuticals and the implications for biosimilars. Nat Rev Drug Discov 11(7): 527-540.

65. Ventola CL (2013) Biosimilars: part 1: proposed regulatory criteria for FDA approval. P T 38(5): 270287.

66. Abas A (2011) Regulatory guidelines for biosimilars in Malaysia. Biologicals 39(5): 339-342.

67. Sullivan PM, DiGrazia LM (2017) Analytic characterization of biosimilars. Am J Health Syst Pharm 74(8): 568-579.

68. Wadhwa M, Bird C, Dougall T, Rigsby P, Bristow A, et al. (2015) Establishment of the first international standard for PEGylated granulocyte colony stimulating factor (PEG-G-CSF): report of an international collaborative study. J Immunol Methods 416: 17-28.

69. Tan Q, Guo Q, Fang C, Wang C, Li B, et al. (2012) Characterization and comparison of commercially 


\section{Bioequivalence \& Bioavailability International Journal}

available TNF receptor 2-Fc fusion protein products. MAbs 4(6): 761-774.

70. Jiang XR, Song A, Bergelson S, Arroll T, Parekh B, et al. (2011) Advances in the assessment and control of the effector functions of therapeutic antibodies. Nat Rev Drug Discov 10(2): 101-111.

71. Jolicoeur P, Tacey RL (2012) Development and validation of cell-based assays for the detection of neutralizing antibodies to drug products: a practical approach. Bioanalysis 4(24): 2959-2570.

72. Rathore A (2012) Guidelines on similar biologics: regulatory requirements for marketing authorization in India. PDA J Pharm Sci Technol 66(5): 393.

73. Reinisch W, Smolen J (2015) Biosimilar safety factors in clinical practice. Semin Arthritis Rheum. 44(6): S915.

74. Barbosa MD, Kumar S, Loughrey H, Singh SK (2012) Biosimilars and biobetters as tools for understanding and mitigating the immunogenicity of biotherapeutics. Drug Discov Today 17(23-24): 12821288.

75. Storz U (2017) Of patents and patent disputes: The TNFalpha patent files. Part 1: Humira. Hum Antibodies 25(1-2): 1-16.

76. Shire SJ (2005) Monoclonal Antibodies: Meeting the Challenges in Manufacturing, Formulation, Delivery and Stability of Final Drug Product: Woodhead Publishing.

77. Chang BS, Hershenson S (2002) Practical approaches to protein formulation development. Pharm Biotechnol 13: 1-25.

78. Robinson NE, Robinson AB (2001) Prediction of protein deamidation rates from primary and threedimensional structure. Proc Natl Acad Sci USA. 98(8): 4367-4372.

79. Pikal-Cleland KA, Carpenter JF (2001) Lyophilizationinduced protein denaturation in phosphate buffer systems: monomeric and tetrameric betagalactosidase. J Pharm Sci 90(9): 1255-1268.

80. Pikal-Cleland KA, Rodriguez-Hornedo N, Amidon GL, Carpenter JF (2000) Protein denaturation during freezing and thawing in phosphate buffer systems: monomeric and tetrameric beta-galactosidase. Arch Biochem Biophys 384(2): 398-406.
81. Piedmonte DM, Treuheit MJ (2008) Formulation of Neulasta (pegfilgrastim). Adv Drug Deliv Rev 60(1): 50-58.

82. Gupta SL, Patel JP, Jones DL, Partipilo RW (1994) Parenteral formulation development of renin inhibitor Abbott-72517. J Pharm Sci Technol 48(2): 86-91.

83. Mahler HC, Huber F, Kishore RS, Reindl J, Ruckert P, et al. (2010) Adsorption behavior of a surfactant and a monoclonal antibody to sterilizing-grade filters. J Pharm Sci 99(6): 2620-2627.

84. Yu J, Anchordoquy TJ (2009) Synergistic effects of surfactants and sugars on lipoplex stability during freeze-drying and rehydration. J Pharm Sci 98(9): 3319-3328.

85. Webb SD, Cleland JL, Carpenter JF, Randolph TW (2002) A new mechanism for decreasing aggregation of recombinant human interferon-gamma by a surfactant: slowed dissolution of lyophilized formulations in a solution containing $0.03 \%$ polysorbate 20. J Pharm Sci 91(2): 543-558.

86. Kishore RS, Kiese S, Fischer S, Pappenberger A, Grauschopf U, et al. (2011) The degradation of polysorbates 20 and 80 and its potential impact on the stability of biotherapeutics. Pharm Res 28(5): 1194-1210.

87. Bravo Gonzalez RC, Huwyler J, Boess F, Walter I, Bittner B (2004) In vitro investigation on the impact of the surface-active excipients Cremophor EL, Tween 80 and Solutol HS 15 on the metabolism of midazolam. Biopharm Drug Dispos 25(1): 37-49.

88. Roginsky V (2003) Chain-breaking antioxidant activity of natural polyphenols as determined during the chain oxidation of methyl linoleate in Triton X100 micelles. Arch Biochem Biophys 414(2): 261-270.

89. Kasraian K, Kuzniar AA, Wilson GG, Wood JA (1999) Developing an injectable formula containing an oxygen-sensitive drug: a case study of danofloxacin injectable. Pharm Dev Technol 4(4): 475-480.

90. Yin J, Chu JW, Ricci MS, Brems DN, Wang DI, et al. (2004) Effects of antioxidants on the hydrogen peroxide-mediated oxidation of methionine residues in granulocyte colony-stimulating factor and human parathyroid hormone fragment 13-34. Pharm Res 21(12): 2377-2383. 


\section{Bioequivalence \& Bioavailability International Journal}

91. Timasheff SN (2002) Protein-solvent preferential interactions, protein hydration, and the modulation of biochemical reactions by solvent components. Proc Natl Acad Sci U S A 99(15): 9721-9726.

92. Arakawa T, Ejima D, Tsumoto K, Obeyama N, Tanaka Y, et al. (2007) Suppression of protein interactions by arginine: a proposed mechanism of the arginine effects. Biophys Chem 127(1-2): 1-8.

93. Arakawa T, Prestrelski SJ, Kenney WC, Carpenter JF (2001) Factors affecting short-term and long-term stabilities of proteins. Adv Drug Deliv Rev 46(1-3): 307-326.

94. Prestrelski SJ, Tedeschi N, Arakawa T, Carpenter JF (1993) Dehydration-induced conformational transitions in proteins and their inhibition by stabilizers. Biophys J 65(2): 661-671.

95. Carpenter JF, Prestrelski SJ, Arakawa T (1993) Separation of freezing- and drying-induced denaturation of lyophilized proteins using stressspecific stabilization. I. Enzyme activity and calorimetric studies. Arch Biochem Biophys 303(2): 456-464.

96. Sou T, Kaminskas LM, Nguyen TH, Carlberg R, McIntosh MP, et al. (2013) The effect of amino acid excipients on morphology and solid-state properties of multi-component spray-dried formulations for pulmonary delivery of biomacromolecules. Eur J Pharm Biopharm 83(2): 234-243.

97. Passot S, Fonseca F, Alarcon-Lorca M, Rolland D, Marin M (2005) Physical characterisation of formulations for the development of two stable freeze-dried proteins during both dried and liquid storage. Eur J Pharm Biopharm 60(3): 335-348.

98. Duddu SP, Dal Monte PR (1997) Effect of glass transition temperature on the stability of lyophilized formulations containing a chimeric therapeutic monoclonal antibody. Pharm Res 14(5): 591-595. 